\title{
Non-Alcoholic Fatty Liver Disease and Hypothyroidism: Review of Clinical and Experimental Studies
}

\author{
Tetiana Ranhulova
}

\begin{abstract}
Hypothyroidism is a widespread condition affecting people of different socio-economic background and geographical location. A lot of studies highlight the effect of hypothyroidism on the metabolic processes in various organs, including the liver. On the other hand, liver damage often results in the development of non-alcoholic fatty liver disease; however, the data on the impact of hypothyroidism on liver morphology, which can serve as a direct indicator and marker of liver condition and function, are limited and controversial. In this report, we reviewed the relationship between non-alcoholic fatty liver disease and hypothyroidism with an accent on morphological alteration of the liver discovered in clinical and experimental studies.

Keywords

Non-Alcoholic Fatty Liver Disease; Hypothyroidism; Ultrasonography; Histopathology

Department of Human Anatomy, Ivano-Frankivsk National Medical University, Ivano-Frankivsk, Ukraine

*E-mail: tania713218@gmail.com

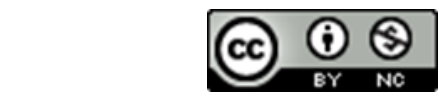

Copyright @Tetiana Ranhulova, 2021
\end{abstract}

\section{Introduction}

Thyroid gland diseases are common conditions characterized by a systemic effect on the human body [1]. The number of individuals with hypothyroidism significantly exceeds the prevalence rates of hypothyroidism, which is largely due to geographic dependency and residence in the iodine-deficient areas [2, 3]. Hypothyroidism is characterized by high serum levels of thyroid-stimulating hormone (TSH) and low serum levels of thyroid hormones and free thyroxine (fT4) [3]. On the other hand, increased TSH ( $>4.0$ to $<10 \mathrm{mU} / 1$ for hypothyroidism grade IA and $\geq 10 \mathrm{mU} / 1$ for hypothyroidism grade IB) can be accompanied by normal levels of free triiodothyronine (fT3) and fT4 with no clinical symptoms; (sub) hypothyroidism is defined biochemically [4]. At the same time, the upper normal limit of TSH, interpreted via laboratory studies, depends on many factors and conditions [5].

Reduced thyroid hormone levels are usually associated with hypometabolism. This condition is defined as weight gain, decline in resting energy expenditure, reduced gluconeogenesis, and lipolysis. Thyroid dysfunction can provoke obesity, lipid metabolism disorders, which are the components of metabolic syndrome [6, 7]. Hypothyroidism reduces lipolysis and gluconeogenesis, thereby impairing triglyceride clearance and fatty acid $\beta$-oxidation, as well as increasing hepatic triglyceride accumulation and low-density lipoprotein reuptake [8].
Non-alcoholic fatty liver disease (NAFLD) is a new global health challenge and its association with other metabolic pathologies has been one of the main research topics in the last decade [9]. The etiological spectrum of NAFLD development involves the presence of comorbidity, viral infections, sociodemographic factors [10, 11]. Furthermore, most patients with NAFLD suffer from undiagnosed primary hypothyroidism [6], which can serve as an inducing factor. Therefore, hypothyroidism-induced NAFLD is regarded as a separate clinical entity [12]. At the same time, the mechanisms of liver dysfunction and morphological changes observed in its damage are not fully understood $[7,8]$. This review is aimed to summarize the data regarding the relationship between hypothyroidism and NAFLD, with an accent on morphological alteration discovered in clinical and experimental studies.

\section{Materials and Methods}

The search was carried out in Web of Science Core Collection database in March 2021 and updated in October 2021. English-language papers published from 2016 to 2021 were considered. Clinical studies were considered for analysis if they involved patients with hypothyroidism (including subclinical hypothyroidism) and coexistent (ultrasound- and/or biopsy-proven) NAFLD. Experimental studies involving animals (rats) with experimentally induced hypothyroidism were included in the review if liver morphology was evalu- 
ated by histological methods.

\section{Clinical Studies}

Clinical studies play a significant role in understanding NAFLD prevalence (Table 1), its relationship with thyroid pathology; they induce further studies on the pathogenetic mechanisms and the development of new diagnostic and therapeutic methods.

Ultrasound imaging is widely used in clinical diagnosis, being a rather specific and sensitive method for detecting hepatic steatosis; its non-invasiveness allows for obtaining real-time results $[13,14]$. In fatty infiltration in less than $30 \%$ of hepatocytes, however, the accuracy of ultrasound imaging has been proven to decrease significantly that justifies the advisability of using the pathohistological method (biopsy) $[15,16]$. At the same time, development of fibrosis in NAFLD is a common pathohistological finding as well [17]. This highlights the importance of applying elastography to assess significant and advanced fibrosis [18, 19].

Table 1. NAFLD and hypothyroidism: clinical studies.

\begin{tabular}{|c|c|c|c|c|c|c|}
\hline$\#$ & Authors (year) & Study & $\begin{array}{l}\text { Liver Morphology } \\
\text { Assessment }\end{array}$ & $\begin{array}{l}\text { Thyroid } \\
\text { Function } \\
\text { Assessment }\end{array}$ & Key Findings & Ref \\
\hline 1 & $\begin{array}{l}\text { D'Ambrosio R } \\
\text { et al. (2021) }\end{array}$ & $\begin{array}{l}\text { Retrospective } \\
\text { single center } \\
\text { study, } \\
52 \text { subjects } \\
\text { (ET (38) - } \\
55(28-72) \text { years, } \\
\text { H (14) - 50 } \\
(30-73) \text { years) }\end{array}$ & $\begin{array}{l}\text { - Liver biopsy: } \\
\text { NAFLD activity } \\
\text { score, fibrosis as- } \\
\text { sessment (Kleiner } \\
\text { classification) } \\
\text { - Stiffness } \\
\text { measurement } \\
\text { (transient elastog- } \\
\text { raphy) }\end{array}$ & $\begin{array}{l}\text { TSH, fT3, fT4, } \\
\text { rT3, Tg-Ab, } \\
\text { TPO-Ab }\end{array}$ & $\begin{array}{l}\text { - Prevalence of NAFLD is higher } \\
\text { among patients with hypothy- } \\
\text { roidism. } \\
\text { - No association between hy- } \\
\text { pothyroidism and severity of } \\
\text { steatosis and fibrosis was found. } \\
\text { - Liver stiffness does not signifi- } \\
\text { cantly differ in hypo- and euthy- } \\
\text { roid patients. }\end{array}$ & [6] \\
\hline 2 & $\begin{array}{l}\text { Choi SY et al. } \\
(2021)\end{array}$ & $\begin{array}{l}\text { Retrospective } \\
\text { multi-center } \\
\text { study, } \\
428 \text { subjects } \\
\text { (ET (370) }-12.16 \\
\pm 2.97 \text { years, } \\
\text { SH (58) - } \\
12.19 \pm 3.31 \text { years) }\end{array}$ & $\begin{array}{l}\text { - Ultrasonography } \\
\text { - APRI score }\end{array}$ & $\mathrm{TSH}, \mathrm{fT} 4$ & $\begin{array}{l}\text { - Subclinical hypothyroidism } \\
\text { was found in } 13.6 \% \text { patients with } \\
\text { NAFLD. } \\
\text { - Subclinical hypothyroidism } \\
\text { is significantly associated with } \\
\text { steatosis grade (assessed by liver } \\
\text { ultrasonography). }\end{array}$ & [20] \\
\hline 3 & Kim HJ. (2020) & $\begin{array}{l}\text { Retrospective } \\
\text { study, } \\
77 \text { subjects } \\
\text { (ET (60) - } 9(1-17) \\
\text { years, } \\
\text { SH (17) - } 5(1-17) \\
\text { years) }\end{array}$ & - Ultrasonography & TSH, fT4. & $\begin{array}{l}\text { - The incidence of NAFLD was } \\
\text { similar among euthyroid patients } \\
\text { and patients with subclinical hy- } \\
\text { pothyroidism. } \\
\text { - The presence and severity of } \\
\text { NAFLD are not significant risk } \\
\text { factors for subclinical hypothy- } \\
\text { roidism. }\end{array}$ & {$[25]$} \\
\hline 4 & $\begin{array}{l}\text { Grewal H et al. } \\
(2020)\end{array}$ & $\begin{array}{l}\text { Prospective } \\
\text { cross-sectional } \\
\text { study, } \\
200 \text { subjects } \\
\text { (ET }(100)-46.18 \\
\pm 13.90 \text { years, } \\
\text { H }(100)-43.79 \\
\pm 13.41 \text { years })\end{array}$ & $\begin{array}{l}\text { - Ultrasonography } \\
\text { (evidence and } \\
\text { grade of hepatic } \\
\text { steatosis) }\end{array}$ & TSH, T3, T4 & $\begin{array}{l}\text { - Ultrasonography-proven } \\
\text { NAFLD is more prevalent in } \\
\text { hypothyroid patients. } \\
\text { - The severity of fatty liver dis- } \\
\text { ease is higher in hypothyroid pa- } \\
\text { tients with higher values of body } \\
\text { mass index. } \\
\text { - Hypothyroidism is significant } \\
\text { risk factor for NAFLD develop- } \\
\text { ment. }\end{array}$ & [21] \\
\hline 5 & $\begin{array}{l}\text { Tahara K et al. } \\
\text { (2019) }\end{array}$ & $\begin{array}{l}\text { Cross-sectional } \\
\text { study, } \\
140 \text { subjects } \\
(\text { ET (70) }-68.3 \\
\pm 7.3 \text { years, } \\
\text { SH (70) }-69.1 \\
\pm 8.1 \text { years) }\end{array}$ & $\begin{array}{l}\text { - Ultrasonography } \\
\text { - FIB-4 index }\end{array}$ & TSH, fT4 & $\begin{array}{l}\text { - The prevalence of NAFLD } \\
\text { and FIB-4 index are significantly } \\
\text { higher among patients with sub- } \\
\text { clinical hypothyroidism. } \\
\text { - TSH levels are significantly as- } \\
\text { sociated with NAFLD. }\end{array}$ & {$[22]$} \\
\hline
\end{tabular}




\begin{tabular}{|c|c|c|c|c|c|c|}
\hline$\#$ & Authors (year) & Study & $\begin{array}{l}\text { Liver Morphology } \\
\text { Assessment }\end{array}$ & $\begin{array}{l}\text { Thyroid } \\
\text { Function } \\
\text { Assessment }\end{array}$ & Key Findings & Ref \\
\hline 6 & $\begin{array}{l}\text { Kim D et al. } \\
(2018)\end{array}$ & $\begin{array}{l}\text { Cross-sectional } \\
\text { study, } \\
425 \text { subjects } \\
\text { (strict-normal } \\
\text { TSH level (282) - } \\
52.4 \pm 14.9 \text { years, } \\
\text { low-normal } \\
\text { TSH level (84) - } \\
51.6 \pm 16.8 \text { years, } \\
\text { SH (59) - } \\
55.4 \pm 15.4 \text { years) }\end{array}$ & $\begin{array}{l}\text { - Liver biopsy } \\
\text { (hematoxylin and } \\
\text { eosin and Mas- } \\
\text { son's trichrome): } \\
\text { NAFLD (pres- } \\
\text { ence of } 5 \% \\
\text { macrovesicular } \\
\text { steatosis) and } \\
\text { fibrosis assess- } \\
\text { ment (Kleiner } \\
\text { classification) } \\
\text { - Ultrasonography }\end{array}$ & TSH, T4 & $\begin{array}{l}\text { - Higher grades of hepatic steato- } \\
\text { sis and more severe degrees of } \\
\text { hepatocyte balloon degeneration } \\
\text { and fibrosis stage are associated } \\
\text { with higher levels of TSH. } \\
\text { - Risks of NASH and advanced } \\
\text { fibrosis are significantly associ- } \\
\text { ated with higher TSH levels. }\end{array}$ & [23] \\
\hline 7 & $\begin{array}{l}\text { Bano A et al. } \\
(2016)\end{array}$ & $\begin{array}{l}\text { Prospective } \\
\text { cohort study, } \\
9,419 \text { subjects } \\
(64.7 \pm 9.7 \quad \text { years; } \\
\text { H 536) }\end{array}$ & $\begin{array}{l}\text { - Ultrasonography } \\
\text { - Stiffness } \\
\text { measurement } \\
\text { (transient elastog- } \\
\text { raphy) }\end{array}$ & $\begin{array}{l}\text { TSH, fT4, } \\
\text { TPO-Ab }\end{array}$ & $\begin{array}{l}\text { - Increasing NAFLD and risk of } \\
\text { clinically relevant fibrosis is asso- } \\
\text { ciated with increasing TSH lev- } \\
\text { els. } \\
\text { - Higher levels of fT4 decrease } \\
\text { the risk of NAFLD. }\end{array}$ & [24] \\
\hline 8 & $\begin{array}{l}\text { Gökmen F et } \\
\text { al. (2016) }\end{array}$ & $\begin{array}{l}\text { Cohort study, } \\
115 \text { subjects } \\
(\text { ET }(61)-48.44 \\
\pm 13.19 \text { years, } \\
\text { H }(54)-47.98 \\
\pm 11.87 \text { years })\end{array}$ & - Ultrasonography & TSH, fT3, fT4 & $\begin{array}{l}\text { - The prevalence of NAFLD did } \\
\text { not significantly differ between } \\
\text { euthyroid and hypothyroid pa- } \\
\text { tients. } \\
\text { - The fT3/fT4 ratio significantly } \\
\text { differs in patients with and with- } \\
\text { out NAFLD and may serve as } \\
\text { NALFD predictor. }\end{array}$ & [26] \\
\hline
\end{tabular}

Notes: ET - euthyroid patients; H - hypothyroid patients; SH - patients with subclinical hypothyroidism.

Regarding liver damage in hypothyroidism, ultrasoundand/or biopsy-proven NAFLD is more commonly observed in patients with (subclinical) hypothyroidism [6, 20-22]. Several authors have found that increased TSH concentrations are associated with the severity of pathological changes in the liver such as steatosis, balloon degeneration and fibrosis [20, 21, 23]. In addition, thyroid hypofunction has been noted as a statistically significant risk factor for NAFLD development [21-24]. At the same time, other studies have demonstrated no relationship between the prevalence of NAFLD among euthyroid individuals or patients with (subclinical) hypothyroidism [25, 26], as well as between the severity of steatosis and fibrosis and hypothyroidism [6].

\section{Experimental Studies}

Experimental studies play an important role in the determination of morphological alterations or investigation of induced pathological conditions [27]. Thus, Chalouati $\mathrm{H}$ et al. have found irreversible thyroid changes and hypothyroid state caused by subchronic hexachlorobenzene exposure [28] According to Jiang LQ et al., amiodarone may affect lipid profile and cause hypothyroidism [29]. Experimental research conducted by Sarkar D et al. has shown that biochemically proven hypothyroidism may result from a longterm exposure to excessive iodine [30]. On the other hand, according to Duan J et al., high iodine and di-n-butyl phthalate exposure exacerbates autoimmune thyroid disease [31].

At the same time, there have been only a few experimental studies on morphologic alterations of the liver in hypothyroidism (Table 2). Such studies differed significantly in their design. Thus, the Wistar and Sprague-Dawley rats were mainly used in the experiment; however, they differed in body weight and age. Hypothyroidism was induced by subcutaneous $[32,33]$ or intraperitoneal administration [34] of propylthiouracil (PTU), or by adding the reagent to water [35-38], or using intragastric intubation [39]. The duration of administration was quite variable, from 15-21 days [34, 38] to 12 weeks [40].

The assessment of thyroid function is based on the determination of fT3, fT4 and TSH levels. At the same time, the spectrum of biochemical assays of the liver is quite wide, from the determination of basic biochemical markers (AST, ALT) [34] to the assessment of the lipid profile and the state of the prooxidant and antioxidant systems $[32,33,35,37,40]$. In most studies, the parameters were determined in both serum and liver homogenates. At the same time, the results were quite different. Several studies indicated no changes in ALT level $[32,33,37]$ or its increase [35, 40]. AST level mostly increased [32, 33, 40], underwent no changes [37], or decreased, according to Panda S et al. [35]. Regarding the prooxidant and antioxidant systems, in experimental hypothyroidism, the increase 
Table 2. Experimental studies on morphological changes in the liver in hypothyroidism.

\begin{tabular}{|c|c|c|c|c|c|c|}
\hline \# & Authors (year) & $\begin{array}{l}\text { Experimental } \\
\text { Design }\end{array}$ & $\begin{array}{l}\text { Biochemical } \\
\text { Assay }\end{array}$ & $\begin{array}{l}\text { Morphological } \\
\text { Assay }\end{array}$ & $\begin{array}{l}\text { Key Biochemical and Morpho- } \\
\text { logical Findings }\end{array}$ & Ref \\
\hline 1 & $\begin{array}{l}\text { Ayuob NN } \\
\text { et al. }(2019)\end{array}$ & $\begin{array}{l}\text { Male Wistar } \\
\text { rats } \\
(180-200 \mathrm{~g}) \\
\text { Hypothyroidism } \\
\text { (PTU } 6 \mathrm{mg} / \mathrm{kg} / \mathrm{BW} \\
\text { by intragastric } \\
\text { intubation for } 6 \\
\text { weeks) }\end{array}$ & $\begin{array}{l}\text { - T3, T4, TSH } \\
\text { - GSH, NO, } \\
\text { MDA, SOD, } \\
\text { CAT, GPX } \\
\text { - Gene expres- } \\
\text { sion of CAT in } \\
\text { supernatant }\end{array}$ & $\begin{array}{l}\text { - Hematoxylin } \\
\text { and eosin } \\
\text { - Immunohisto- } \\
\text { chemical (strep- } \\
\text { tavidin-biotin- } \\
\text { peroxidase } \\
\text { technique) } \\
\text { - Semi-quanti- } \\
\text { tative analysis } \\
\text { (NAFLD activ- } \\
\text { ity score) }\end{array}$ & $\begin{array}{l}\text { - Significant increase in MDA } \\
\text { and NO. } \\
\text { - Steatosis (fatty degeneration), } \\
\text { diffusely located micro- and } \\
\text { macrovesicles in the hepato- } \\
\text { cytes. } \\
\text { - Steatotic lesion accompanied } \\
\text { by intralobular inflammatory re- } \\
\text { action (NASH). } \\
\text { - CD68+ cell infiltration in the } \\
\text { portal and lobular regions. }\end{array}$ & [39] \\
\hline 2 & $\begin{array}{l}\text { Tasci HI et al. } \\
\text { (2017) }\end{array}$ & $\begin{array}{l}\text { Female Wistar } \\
\text { rats } \\
(260-320 \mathrm{~g}) \\
\text { Hypothyroidism } \\
+ \text { sepsis } \\
(10 \mathrm{mg} / \mathrm{kg} \mathrm{PTU} \text {, } \\
\text { intraperitoneally } \\
\text { for } 15 \text { days + } \\
\text { sepsis modeling } \\
\text { (cecal ligation and } \\
\text { perforation)) }\end{array}$ & $\begin{array}{l}\text { - fT3, fT4, TSH } \\
\text { - AST, ALT }\end{array}$ & $\begin{array}{l}\text { - Hematoxylin } \\
\text { and eosin } \\
\text { - Semi-quanti- } \\
\text { tative eval- } \\
\text { uation of } \\
\text { inflammation, } \\
\text { congestion, } \\
\text { Kupffer cell } \\
\text { hyperplasia, } \\
\text { and hydropic } \\
\text { degeneration. }\end{array}$ & $\begin{array}{l}\text { - Increasing AST and ALT levels } \\
\text { in both groups. } \\
\text { - Negative correlation between } \\
\text { fT3 and AST, ALT levels. } \\
\text { - Inflammatory cell infiltration } \\
\text { and congestion were more severe } \\
\text { in sepsis + hypothyroidism rather } \\
\text { in sepsis + hyperthyroidism. }\end{array}$ & [3] \\
\hline 3 & $\begin{array}{l}\text { Panda S et al. } \\
(2021)\end{array}$ & $\begin{array}{l}\text { Female Wistar } \\
\text { rats } \\
(165 \pm 10 \quad \mathrm{~g}, \\
7 \text { weeks old }) \\
\text { Hypothyroidism } \\
(0.05 \% \text { PTU in } \\
\text { drinking water for } \\
6 \text { weeks) }\end{array}$ & $\begin{array}{l}\text { - T3, T4, and } \\
\text { TSH } \\
\text { - ALT, AST, TC } \\
\text { and TG } \\
\text { - Liver tissue: } \\
\text { MDA, SOD, } \\
\text { CAT, GPX, } \\
\text { GSH, protein } \\
\text { content }\end{array}$ & $\begin{array}{l}\text { - Hematoxylin } \\
\text { and eosin }\end{array}$ & $\begin{array}{l}\text { - Decreasing antioxidants fol- } \\
\text { lowed by increasing lipid peroxi- } \\
\text { dation (MDA). } \\
\text { - Increasing ALT levels accompa- } \\
\text { nied by decreasing AST levels. } \\
\text { - Increasing TC and TG levels. } \\
\text { - Liver histopathology: irregu- } \\
\text { lar orientation of hepatic cords, } \\
\text { necrosis in the centrilobular area, } \\
\text { and inflammatory cell infiltra- } \\
\text { tion. }\end{array}$ & [4] \\
\hline 4 & $\begin{array}{l}\text { Bunker SK et } \\
\text { al. (2018) }\end{array}$ & $\begin{array}{l}\text { Male Wistar } \\
\text { rats } \\
(328 \pm 19.23 \mathrm{~g}, \\
\text { age: } \\
330 \pm 10 \text { days }) \\
\text { Hypothyroidism } \\
(0.05 \% \text { PTU in } \\
\text { drinking water for } \\
30 \text { days) }\end{array}$ & $\begin{array}{l}\text { - T3, T4, TSH } \\
\text { - Liver tissue: } \\
\text { thiobarbituric } \\
\text { acid reactive } \\
\text { substance (lipid } \\
\text { peroxidation) }\end{array}$ & $\begin{array}{l}\text { - Hematoxylin } \\
\text { and eosin } \\
\text { - Morphometry: } \\
\text { counting hepa- } \\
\text { tocytes }\end{array}$ & $\begin{array}{l}\text { - The level of thiobarbutiric acid } \\
\text { reactive substance significantly } \\
\text { increased. } \\
\text { - The number of hepatocyte nu- } \\
\text { clei decreased }(17 \%) \text {. } \\
\text { - Congestion of hepatocytes and } \\
\text { reduction in the sinusoidal space } \\
\text { were observed. }\end{array}$ & {$[5]$} \\
\hline 5 & $\begin{array}{l}\text { Mohibbullah M } \\
\text { et al. (2019) }\end{array}$ & $\begin{array}{l}\text { Male SPF/VAF } \\
\text { outbred and } \\
\text { Sprague- } \\
\text { Dawley rats } \\
(264-318 \mathrm{~g}) \\
\text { Hypothyroidism } \\
\text { (PTU } 10 \mathrm{mg} / \mathrm{kg} \\
\text { subcutaneously for } \\
28 \text { days) }\end{array}$ & $\begin{array}{l}\text { - T3, T4, TSH } \\
\text { - AST, ALT, } \\
\text { TC, LDL, HDL, } \\
\text { TG } \\
\text { - Liver tissue: } \\
\text { MDA, } \mathrm{H}_{2} \mathrm{O}_{2}, \\
\text { CAT, SOD }\end{array}$ & $\begin{array}{l}\text { - Hematoxylin } \\
\text { and eosin } \\
\text { - Morphometry: } \\
\text { counting hepa- } \\
\text { tocytes }\end{array}$ & $\begin{array}{l}\text { - Significantly increasing HDL } \\
\text { levels and decreasing TG levels. } \\
\text { - Significantly increasing } \mathrm{H}_{2} \mathrm{O}_{2} \\
\text { and SOD levels, followed by de- } \\
\text { creasing CAT levels. } \\
\text { - Increasing AST levels, without } \\
\text { affecting ALT levels. } \\
\text { - Swelling and reduced number } \\
\text { of hepatocytes, lipid droplet ac- } \\
\text { cumulation. }\end{array}$ & {$[1]$} \\
\hline
\end{tabular}




\begin{tabular}{|c|c|c|c|c|c|c|}
\hline$\#$ & Authors (year) & $\begin{array}{l}\text { Experimental } \\
\text { Design }\end{array}$ & $\begin{array}{l}\text { Biochemical } \\
\text { Assay }\end{array}$ & $\begin{array}{l}\text { Morphological } \\
\text { Assay }\end{array}$ & $\begin{array}{l}\text { Key Biochemical and Morpho- } \\
\text { logical Findings }\end{array}$ & Ref \\
\hline 6 & $\begin{array}{l}\text { Baki AM et al. } \\
(2020)\end{array}$ & $\begin{array}{l}\text { Male Sprague- } \\
\text { Dawley rats } \\
(250-350 \mathrm{~g}) \\
\text { Hypothyroidism } \\
\text { (PTU } 500 \mathrm{mg} / \mathrm{L} \text { in } \\
\text { drinking water for } \\
10 \text { weeks) }\end{array}$ & $\begin{array}{l}\text { - fT3, fT4 } \\
\text { - Glucose, TC, } \\
\text { TG, albumin, } \\
\text { ALT, AST } \\
\text { - Liver tissue: } \\
\text { ROS, MDA, } \\
\text { SOD, GPX, } \\
\text { ferric reducing } \\
\text { antioxidant } \\
\text { power, oxida- } \\
\text { tive protein } \\
\text { damage }\end{array}$ & $\begin{array}{l}\text { - Hematoxylin } \\
\text { and eosin }\end{array}$ & $\begin{array}{l}\text { - Decreasing glucose and TG lev- } \\
\text { els. } \\
\text { - Increasing TC levels. } \\
\text { - No changes in ALT, AST, and } \\
\text { albumin levels. } \\
\text { - No changes in the levels of } \\
\text { MDA and ROS and oxidative } \\
\text { protein damage. } \\
\text { - No changes in ferric reducing } \\
\text { antioxidant power, SOD, GPX } \\
\text { levels. } \\
\text { - Hydropic degeneration of hepa- } \\
\text { tocytes around central veins fol- } \\
\text { lowed by sinusoidal congestion. }\end{array}$ & [37] \\
\hline 7 & $\begin{array}{l}\text { Lee W-Y et al. } \\
\text { (2017) }\end{array}$ & $\begin{array}{l}\text { Male Sprague- } \\
\text { Dawley rats } \\
\text { (6 weeks old) } \\
\text { Hypothyroidism } \\
\text { (PTU } 10 \mathrm{mg} / \mathrm{kg} \\
\text { subcutaneously for } \\
28 \text { days) }\end{array}$ & $\begin{array}{l}\text { - ALT, AST, } \\
\text { TC, TG, HDL, } \\
\text { LDL } \\
\text { - Liver tissue: } \\
\text { MDA, CAT, } \\
\text { SOD, } \mathrm{H}_{2} \mathrm{O}_{2}\end{array}$ & $\begin{array}{l}\text { - Hematoxylin } \\
\text { and eosin } \\
\text { - Morphometry: } \\
\text { counting hepa- } \\
\text { tocytes }\end{array}$ & $\begin{array}{l}\text { - Increasing } \mathrm{H}_{2} \mathrm{O}_{2} \text {, SOD levels } \\
\text { and decreasing CAT levels; no } \\
\text { changes in MDA levels. } \\
\text { - No changes in ALT levels fol- } \\
\text { lowed by increasing AST levels. } \\
\text { - Increasing HDL levels, without } \\
\text { changing LDL levels; decreasing } \\
\text { TG levels, with no changes in TC } \\
\text { levels. } \\
\text { - Swelling of hepatocytes with } \\
\text { lipid droplet deposition. } \\
\text { - Decrease in hepatocyte } \\
\text { number/mm². }\end{array}$ & [2] \\
\hline 8 & $\begin{array}{l}\text { Ustun YB et } \\
\text { al. (2018) }\end{array}$ & $\begin{array}{l}\text { Male Wistar } \\
\text { rats } \\
(200-250 \mathrm{~g}) \\
\text { Hypothyroidism } \\
\text { (PTU in drinking } \\
\text { water for } 21 \text { days) }\end{array}$ & $\begin{array}{lr}\text { - Liver } & \text { tissue: } \\
\text { CAT, } & \text { GPX, } \\
\text { SOD, } & \text { and } \\
\text { MDA } & \end{array}$ & $\begin{array}{l}\text { - Hematoxylin } \\
\text { and eosin } \\
\text { - Immuno- } \\
\text { histochemical } \\
\text { analysis (Ki67, } \\
\text { insulin-like } \\
\text { growth factor-I) } \\
\text { - Semiquanti- } \\
\text { tative analysis + } \\
\text { cells counting }\end{array}$ & $\begin{array}{l}\text { - No changes in MDA, CAT, } \\
\text { SOD and GPX levels. } \\
\text { - The presence of cytoplasmic } \\
\text { vacuolization, hypereosinophilia, } \\
\text { nuclear pyknosis, necrosis with } \\
\text { impairment of hepatocyte cords, } \\
\text { bleeding, and neutrophilic in- } \\
\text { filtrations have been evaluated; } \\
\text { however, semiquantitative anal- } \\
\text { ysis did not show significant } \\
\text { changes. }\end{array}$ & [7] \\
\hline 9 & $\begin{array}{l}\text { Demir S et al. } \\
\text { (2016) }\end{array}$ & $\begin{array}{l}\text { Male Wistar } \\
\text { rats } \\
(8-12 \text { weeks, } \\
250-330 \mathrm{~g}) \\
\text { Hypothyroidism } \\
\text { (methimazole } \\
0.025 \% \text { in drinking } \\
\text { water for } 12 \text { weeks) }\end{array}$ & $\begin{array}{l}\text { - fT3, fT4, TSH } \\
\text { - Serum glu- } \\
\text { cose, insulin, } \\
\text { visfatin, ALT, } \\
\text { AST, TG, HDL, } \\
\text { LDL }\end{array}$ & $\begin{array}{l}\text { - Hematoxylin } \\
\text { and eosin } \\
\text { - Oil Red-O } \\
\text { staining }\end{array}$ & $\begin{array}{l}\text { - Increasing AST and ALT, LDL, } \\
\text { fasting glucose levels. } \\
\text { - Mild steatosis, microscopic } \\
\text { hepatosteatosis, microvesicular } \\
\text { lipid vacuoles with sharp edges } \\
\text { in hepatocytes. Mild parenchy- } \\
\text { mal degeneration. Mild mononu- } \\
\text { clear cell infiltrations in the por- } \\
\text { tal regions. }\end{array}$ & [40] \\
\hline
\end{tabular}

Notes: CAT - catalase; GSH - reduced glutathione; GPX - glutathione peroxidase; HDL, LDL - high- and low-density lipoprotein cholesterol; MDA - malondialdehyde; NO - nitric oxide; PTU - propylthiouracil; SOD - superoxide dismutase; TG - triglycerides; TC - total cholesterol; ROS - reactive oxygen species.

in lipid peroxidation $[35,36,39]$ and deterioration in the antioxidant state were observed [32, 33, 35]. At the same time, several studies have found no significant changes in these systems $[37,38]$.

On the other hand, morphological studies are typical and are limited to using hematoxylin-eosin. Only several studies used the other histological [40] and immunohistochemical methods [38, 39]. Morphological confirmation is descriptive; the semi-quantitative methods or cell counting are sometimes used [32, 33, 37, 38]. Most studies indicate 
hepatocyte swelling, cytoplasmic vacuolization, accumulation of lipid inclusions [32, 33, 37, 38, 40] followed by a decrease in the number of hepatocytes $[32,33,36]$ and inflammatory cell infiltration [34, 35, 38-40].

\section{Limitations}

This review has several limitations according to its objective. First, the search was carried out in Web of Science Core Collection database only and was limited to the articles published from 2016 to 2021. Second, studies reported liver damage confirmed by biochemical assays and/or surrogate markers only were not considered. In addition, this review did not include the results of studies involving euthyroid patients or subjects with elevated thyroid hormone levels (without hypothyroidism).

\section{Conclusions}

According to the results of clinical studies, hypothyroidism is one of the risk factors for NAFLD development. However, it is difficult to make comparison between these studies as they involve groups of subjects who differ in age, gender, geographical location. Experimental morphological studies are mainly focused on descriptive or semiquantitative histopathological analysis. Therefore, timedependency between hypothyroidism, severity of NAFLD and progression of morphological alteration is still unclear and requires future studies.

\section{Ethical Statement}

This report does not include any human subjects and animals.

\section{Conflict of Interest}

The author declares that no conflicts exist.

\section{Financial Disclosure}

The author declared no financial support.

\section{References}

[1] Toloza FJK, Mao Y, Menon L, George G, Borikar M, Thumma S, et al. Association of thyroid function with suicidal behavior: a systematic review and metaanalysis. Medicina. 2021;57(7):714. Available from: https://doi.org/10.3390/medicina57070714

[2] Taylor PN, Albrecht D, Scholz A, Gutierrez-Buey G, Lazarus JH, Dayan CM, et al. Global epidemiology of hyperthyroidism and hypothyroidism. Nature Reviews Endocrinology. 2018;14(5):301-316. Available from: https://doi.org/10.1038/nrendo.2018.18

[3] Chiovato L, Magri F, Carlé A. Hypothyroidism in context: where we've been and where we're going. Advances in Therapy. 2019;36(S2):47-58. Available from: https://doi.org/10.1007/s12325-019-01080-8
[4] Wiersinga WM. Guidance in subclinical hyperthyroidism and subclinical hypothyroidism: are we making progress? European Thyroid Journal. 2015;4(3):143-148. Available from: https://doi.org/10.1159/000438909

[5] Biondi B, Cappola AR, Cooper DS. Subclinical hypothyroidism. JAMA. 2019;322(2):153. Available from: https://doi.org/10.1001/jama.2019.9052

[6] D’Ambrosio R, Campi I, Maggioni M, Perbellini R, Giammona E, Stucchi R, et al. The relationship between liver histology and thyroid function tests in patients with non-alcoholic fatty liver disease (NAFLD). PLOS ONE. 2021;16(4):e0249614. Available from: https://doi.org/10.1371/journal.pone.0249614

[7] Notariza KR, Wisnu W. The risk of developing non-alcoholic fatty liver disease in adult patients with subclinical hypothyroidism compared to euthyroid: an evidence-based case report. Acta Med Indones. 2019;51(2):179-188. Available from: http://www.actamedindones.org/index.php/ijim

[8] Kizivat T, Maric I, Mudri D, Curcic IB, Primorac D, Smolic M. Hypothyroidism and nonalcoholic fatty liver disease: pathophysiological associations and therapeutic implications. Journal of Clinical and Translational Hepatology. 2020;8(3):1-7. Available from: https://doi.org/10.14218/JCTH.2020.00027

[9] Tanase DM, Gosav EM, Neculae E, Costea CF, Ciocoiu M, Hurjui LL, et al. Hypothyroidism-induced nonalcoholic fatty liver disease (HIN): mechanisms and emerging therapeutic options. International Journal of Molecular Sciences. 2020;21(16):5927. Available from: https://doi.org/10.3390/ijms21165927

[10] Lonardo A, Mantovani A, Lugari S, Targher G. NAFLD in some common endocrine diseases: prevalence, pathophysiology, and principles of diagnosis and management. International Journal of Molecular Sciences. 2019;20(11):2841. Available from: https://doi.org/10.3390/ijms20112841

[11] Mansour-Ghanaei F, Joukar F, Mobaraki SN, Mavaddati S, Hassanipour S, Sepehrimanesh M. Prevalence of non-alcoholic fatty liver disease in patients with diabetes mellitus, hyperlipidemia, obesity and polycystic ovary syndrome: a cross-sectional study in north of Iran. Diabetes \& Metabolic Syndrome: Clinical Research \& Reviews. 2019;13(2):1591-1596. Available from: https://doi.org/10.1016/j.dsx.2019.03.009

[12] Manka P, Bechmann L, Best J, Sydor S, Claridge LC, Coombes JD, et al. Low free triiodothyronine is associated with advanced fibrosis in patients at high risk for nonalcoholic steatohepatitis. Digestive Diseases and Sciences. 2019;64(8):2351-2358. Available from: https://doi.org/10.1007/s10620-019-05687-3 
[13] Chang T-Y, Chang S-H, Lin Y-H, Ho W-C, Wang CY, Jeng W-J, et al. Utility of quantitative ultrasound in community screening for hepatic steatosis. Ultrasonics. 2021;111:106329. Available from: https://doi.org/10.1016/j.ultras.2020.106329

[14] Saverymuttu SH, Joseph AE, Maxwell JD. Ultrasound scanning in the detection of hepatic fibrosis and steatosis. BMJ. 1986;292(6512):13-15. Available from: https://doi.org/10.1136/bmj.292.6512.13

[15] Kondo R, Kusano H, Mihara Y, Kage M, Akiba J, Yano H. Pathological findings of liver steatosis that is difficult to evaluate with ultrasound. Journal of Medical Ultrasonics. 2021;48:515-522. Available from: https://doi.org/10.1007/s10396-021-01126-X

[16] Petzold G, Lasser J, Rühl J, Bremer SCB, Knoop RF, Ellenrieder V, et al. Diagnostic accuracy of B-Mode ultrasound and Hepatorenal Index for graduation of hepatic steatosis in patients with chronic liver disease. PLOS ONE. 2020;15(5):e0231044. Available from: https://doi.org/10.1371/journal.pone.0231044

[17] Shetty D, Amarapurkar A, Shukla A. Primary versus secondary NAFLD: perspective on advanced fibrosis. Journal of Clinical and Experimental Hepatology. 2021;11(5):557-564. Available from: https://doi.org/10.1016/j.jceh.2020.12.009

[18] Sharpton SR, Tamaki N, Bettencourt R, Madamba E, Jung J, Liu A, et al. Diagnostic accuracy of two-dimensional shear wave elastography and transient elastography in nonalcoholic fatty liver disease. Therapeutic Advances in Gastroenterology. 2021;14:175628482110504. Available from: https://doi.org/10.1177/17562848211050436

[19] Taibbi A, Petta S, Matranga D, Caruana G, Cannella R, Busè $\mathrm{G}$, et al. Liver stiffness quantification in biopsyproven nonalcoholic fatty liver disease patients using shear wave elastography in comparison with transient elastography. Ultrasonography. 2021;40(3):407-416. Available from: https://doi.org/10.14366/usg.20147

[20] Choi SY, Yi DY, Kim SC, Kang B, Choe B$\mathrm{H}$, Lee $\mathrm{Y}$, et al. Severe phenotype of nonalcoholic fatty liver disease in pediatric patients with subclinical hypothyroidism: a retrospective multicenter study from Korea. Journal of Korean Medical Science. 2021;36(20). Available from: https://doi.org/10.3346/jkms.2021.36.e137

[21] Grewal H, Joshi S, Sharma R, Mittal P, Goel A. Non-alcoholic fatty liver disease in patients with hypothyroidism presenting at a rural tertiary care centre in north India. Tropical Doctor. 2020;51(2):181-184. Available from: https://doi.org/10.1177/0049475520945058

[22] Tahara K, Akahane T, Namisaki T, Moriya K, Kawaratani H, Kaji K, et al. Thyroid-stimulating hormone is an independent risk factor of non-alcoholic fatty liver disease. JGH Open. 2019;4(3):400-404. Available from: https://doi.org/10.1002/jgh3.12264

[23] Kim D, Kim W, Joo SK, Bae JM, Kim JH, Ahmed A. Subclinical hypothyroidism and low-normal thyroid function are associated with nonalcoholic steatohepatitis and fibrosis. Clinical Gastroenterology and Hepatology. 2018;16(1):123-131.e1. Available from: https://doi.org/10.1016/j.cgh.2017.08.014

[24] Bano A, Chaker L, Plompen EPC, Hofman A, Dehghan A, Franco OH, et al. Thyroid function and the risk of nonalcoholic fatty liver disease: the Rotterdam study. The Journal of Clinical Endocrinology \& Metabolism. 2016;101(8):3204-3211. Available from: https://doi.org/10.1210/jc.2016-1300

[25] Kim HJ. Importance of thyroid-stimulating hormone levels in liver disease. Journal of Pediatric Endocrinology and Metabolism. 2020;33(9):1133-1137. Available from: https://doi.org/10.1515/jpem-2020-0031

[26] Gökmen F, Ahbab S, Ataoğlu H, Türker B, Çetin F, Türker F, et al. FT3/FT4 ratio predicts non-alcoholic fatty liver disease independent of metabolic parameters in patients with euthyroidism and hypothyroidism. Clinics. 2016;71(4):221-225. Available from: https://doi.org/10.6061/clinics/2016(04)08

[27] Kotyk T, Tokaruk N, Bedej V, Hryshchuk M, Popadynets $\mathrm{O}$, Kolinko Y, et al. Multi-step clustering approach of myelinated nerve fibers in experimental neuromorphology. International Journal of Ambient Computing and Intelligence. 2021;12(2):73-91. Available from: https://doi.org/10.4018/IJACI.2021040105

[28] Chalouati H, Gamet-Payrastre L, Saad MB. Irreversible thyroid disruption induced after subchronic exposure to hexachlorobenzene in male rats. Toxicology and Industrial Health. 2013;32(5):822-831. Available from: https://doi.org/10.1177/0748233713511511

[29] Jiang L-Q, Chen S-J, Xu J-J, Ran Z, Ying W, Zhao SG. Dronedarone and amiodarone induce dyslipidemia and thyroid dysfunction in rats. Cellular Physiology and Biochemistry. 2016;38(6):2311-2322. Available from: https://doi.org/10.1159/000445585

[30] Sarkar D, Chakraborty A, Saha A, Chandra AK. Iodine in excess in the alterations of carbohydrate and lipid metabolic pattern as well as histomorphometric changes in associated organs. Journal of Basic and Clinical Physiology and Pharmacology. 2018;29(6):631-643. Available from: https://doi.org/10.1515/jbcpp-2017-0204

[31] Duan J, Kang J, Deng T, Yang X, Chen M. Exposure to DBP and high iodine aggravates autoimmune thyroid disease through increasing the levels of IL-17 and thyroid-binding globulin in Wistar rats. Toxicological Sciences. 2018;163(1):196-205. Available from: https://doi.org/10.1093/toxsci/kfy019 
[32] Mohibbullah M, Bashir KMI, Kim S, Hong Y, Kim A, $\mathrm{Ku} \mathrm{S}$, et al. Protective effects of a mixed plant extracts derived from Astragalus membranaceus and Laminaria japonica on PTU-induced hypothyroidism and liver damages. Journal of Food Biochemistry. 2019;43(7). Available from: https://doi.org/10.1111/jfbc.12853

[33] Lee W-Y, Yi S-J, Yun S, Oh T-H, Kim H-T, Lim M$\mathrm{K}$, et al. Hepatoprotective effect of blue honeysuckle on rat hypothyroidism. Journal of Veterinary Clinics. 2017;34(6):404-409. Available from: https://doi.org/10.17555/jvc.2017.12.34.6.404

[34] Tasci HI, Erikoglu M, Toy H, Karaibrahimoglu A. Course of sepsis in rats with thyroid dysfunction. Turkish Journal of Surgery. 2017;33(3):175-179. Available from: https://doi.org/10.5152/turkjsurg.2017.3621

[35] Panda S, Kar A, Singh M, Singh RK, Ganeshpurkar A. Syringic acid, a novel thyroid hormone receptor$\beta$ agonist, ameliorates propylthiouracil-induced thyroid toxicity in rats. Journal of Biochemical and Molecular Toxicology. 2021;35(8). Available from: https://doi.org/10.1002/jbt.22814

[36] Bunker SK, Dutta A, Pradhan J, Dandapat J, Chainy GBN. Curcumin restores hepatic epigenetic changes in propylthiouracil(PTU) Induced hypothyroid male rats: A study on DNMTs, MBDs, GADD45a, C/EBP- $\beta$ and PCNA. Food and Chemical Toxicology. 2019;123:169-180. Available from: https://doi.org/10.1016/j.fct.2018.10.050

[37] Baki AM, Aydın AF, Vural P, et al. $\alpha$-lipoic acid ameliorates the changes in prooxidantantioxidant balance in liver and brain tissues of propylthiouracil-induced hypothyroid rats. Cell Journal. 2020;22:117-124. Available from: https://doi.org/10.22074/cellj.2020.7049

[38] Ustun YB, Kaya C, Koksal E, Atalay Y, Yilmaz Z, Torun AC, et al. Effects of the administration of thyroid hormones in cases of hepatic ischemia and reperfusion injury. International Surgery. 2018;103(5-6):260-269. Available from: https://doi.org/10.9738/INTSURGD-17-00108.1

[39] Ayuob NN, Abdel-Hamid AAHM, Helal GMM, Mubarak WA. Thymoquinone reverses nonalcoholic fatty liver disease (NAFLD) associated with experimental hypothyroidism. Romanian journal of morphology and embryology. 2019;60:479-486.

[40] Demir Ş, Ünübol M, Aypak SÜ, İpek E, Aktaş S, Ekren GS, et al. Histopathologic evaluation of nonalcoholic fatty liver disease in hypothyroidism-induced rats. International Journal of Endocrinology. 2016;2016:1-7. Available from: https://doi.org/10.1155/2016/5083746

Received: $2021-04-10$

Revision Requested: 2021-11-04

Revision Received: 2021-11-08

Accepted: 2021-11-15 